\title{
Fenvalerate Induced Changes in Histological Structure of Gonads of Freshwater Teleost Fish Barbus Carnaticus
}

\author{
A M Vibhandik"1, R B Gaikwad ${ }^{2}$, G P Wani ${ }^{3}$
}

${ }^{1}$ Swami Muktanand College of Science, Department of Zoology, Yeola, Dist. Nasik, Maharashtra India

${ }^{2}$ Department of Zoology, S.M.D.M. College Kallamb, Dist. Osmanabad, Maharashtra India

${ }^{3}$ Post Graduate and Research Department of Zoology. B. P. Arts, S.M.A. science and K.K.C. commerce College, Chalisgaon, Dist. Jalgaon, Maharashtra, India

\section{ABSTRACT}

In the present study freshwater teleost fish Barbus carnaticus used as a specimen to observe the concentration based effects of Fenvalerate on the Ovary and Testicular structure, Concentration mediated histopathological lessions were observed in the Ovary and Testis of Barbus carnaticus exposed to LC 50 concentrations of Fenvalerate for 24, 48, 72 and 96 hours. Conclusion drawn from the study is that the structure of Ovary and Testis is highly damaged at LC 50 concentration for 96 hours duration. Damage of germinal epithelium inflammation, contraction, condensation in the cells of Ovary and Testicular tubules are observed.

Keywords :- Barbus carnaticus, Fenvalerate, Histology, Ovary, Testis

\section{INTRODUCTION}

Fish is highly nutritive food for human beings. Enough water bodies are available in our country which is used consistently for fishery. It is possible to increase aquatic food production by adopting aquaculture practices even at small scale. But the production of fish is being adversely affected due to non sustainable activities of man that exert both direct and indirect effects upon aquatic fauna including fish. Changes in the physico chemical status of the aquatic environment is done by releasing untreated industrial and domestic effluents. The polluted water destroys the suitable conditions needed for healthy fish population and it also cause damage to the metabolism of fishes leading to large scale mortality. Indiscriminate use of pesticides and chemical fertilizers leads to pollution of water bodies. It leads to the decrease in the population as the gonads are exposed to pesticides in various lethal concentrations. Gonads have a series of developmental changes with the onset of maturation which are closely accompanied by conspicuous cellular, biochemical, molecular and endocrinological changes. (Nagahama, 1983, Guraya, 2000). Polluted aquatic environment cause decrease in the population of fish species.

\section{METHODS AND MATERIAL}

The toxicity tests were conducted as per the recommendations of APHA (1998). Fish Barbus carnaticus (approx.wt. 100 g.) were collected from the Girna Dam, constructed on Girna river in Dist: Nasik, Maharashtra and acclimated to the laboratory conditions for a period of 15 days in a large tank of 1000 liter, previously washed with potassium permanganate and water temperature was $26 \pm 350 \mathrm{c}$ and $\mathrm{pH} 7.0-7.2$ maintained in aquarium. At the termination of the experiment both control and treated fish were dissected in Ringers solution. Ovaries and Testis were excised, quickly separated 
from the adjoining tissues and sections were taken 8 micron with the help of rotary microtome, then stained in Haematoxylene, Eosin and mounted in DPX for microscopic examination.

\section{RESULTS AND DISCUSSION}

The ovary of normal Barbus carnaticus reveals that it is surrounded by an ovarian wall which is differentiated into an outer thin peritoneum a thicker tunica albuginea, made up of connective tissue, muscle fibers and blood capillaris.

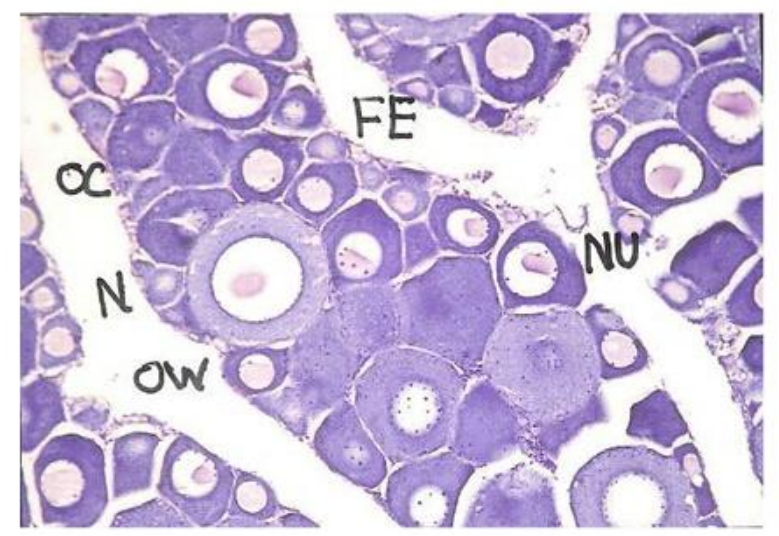

Fig 1 - T. S. of ovary from Barbus carnaticus (Control). OC- Oocyte, NU - Nucleolus, N - Nucleus, OW Ovarian Wall.

The innermost layer is the germinal epithelium which joins with the tunica albuginea at several places and projects into the central lumen of the ovocoelom show finger like projections called ovigerous lamellae (Fig 1).

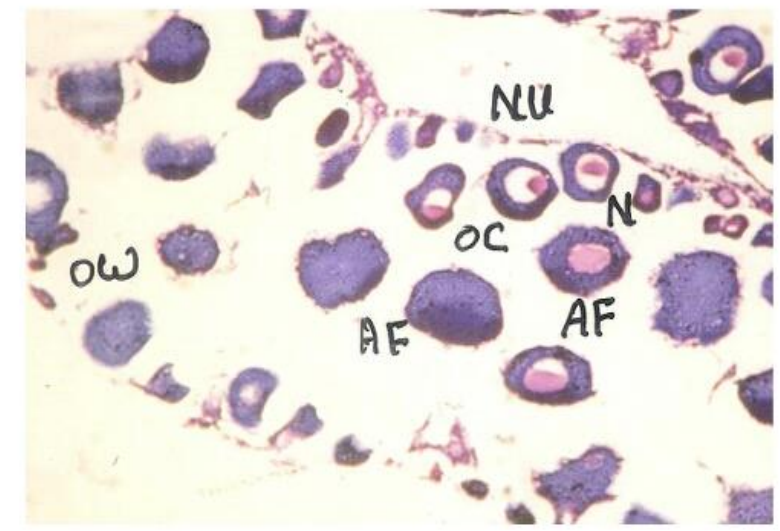

Fig 2 - T .S. of ovary from B. carnaticus (Exposed to Fenvelarate for $96 \mathrm{~h}$ ).

OC - Oocyte, NU - Nucleolus, N - Nucleus, OW Ovarian Wall, AF-Atretic Follicle.

The histology of experimental fish ovary showed disrupted follicular epithelial cells. Nucleolus showed condensation of crescent shaped dark granules at one side. Degeneration of epithelial cells causes vacuolization, breakdown of germinal vesicles, many disrupted oogonia (Fig 2).Most of the workers have shown that the fishes exposed to pesticides led to lowered steroid genesis Kapur et al;1978. Stopage of development of advanced oocyte stages and thus reducing the number of viable oocytes ( Saxena \& Garg 1978, Yasuno et al ; 1980, Mani \& Saxena 1985). The increase in follicular atresia was obvious due to effect of pesticides on fish ovary. Both inhibited the growth of oocytes and raised incidences of follicular atresia were evident in ovary of Channa orientalis exposed to Nuvan Dimecron as have been observed in the case of certain fishes (Shukla et al ;1900, Mani \& Saxena 1985, Ghosh 1986, Singh \& Sahai 1986, Khillare \& Wagh 1987, Patwardhan \& Gaikwad 1990, Dutta et al; 1994.The histological abnormalities in ovaries may be due to factors like ionizing radiations, electric current, parasitic infections. Xenobiotic toxicants. Sarojini and Victor (1985) and by variety of effluents and aquatic pollutants (Shukla et al; 1984 
Saxena \& Garg1978 Johnson et al ; 1988 Mc Comic et al 1989 Kumar et al; 2000.) Almost all similar histopathological findings were reported by Hossain et al; 2002 in the ovaries Anabas testudineus.

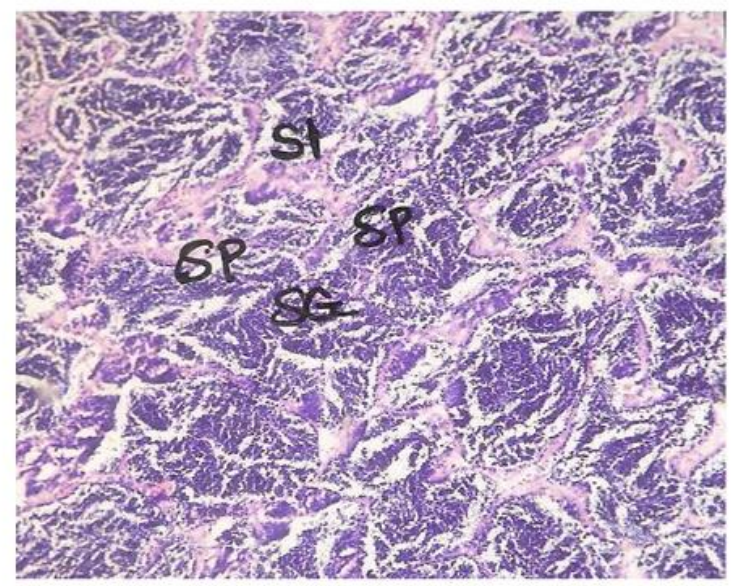

Fig 3. T. S. of testis from B. carnaticus (control). SL-Seminiferous Lobule, SG- Spernatogonia, SPSpermatids.

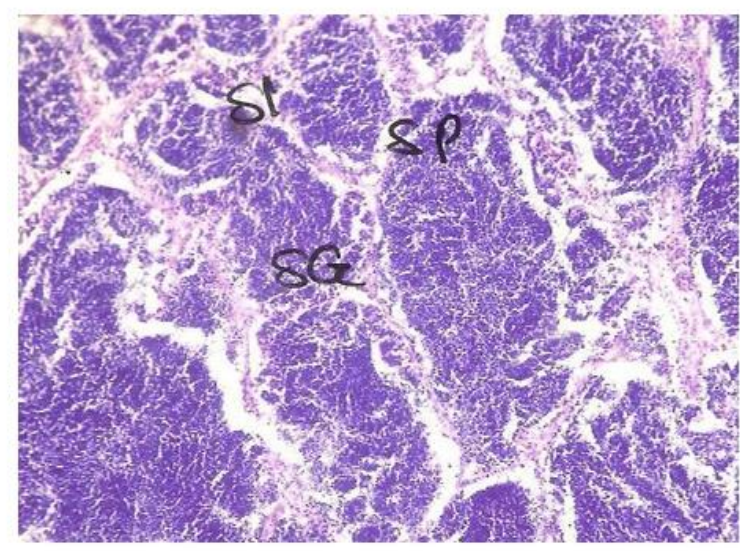

Fig 4. T.S .of Testis from B. carnaticus (Exposed to Fenvalerate for $96 \mathrm{~h}$ ).

SL-Seminiferous Lobule, SG- Spernatogonia, SPSpermatids

Testis of Barbus carnaticus are paired organs found in abdominal region and each is enclosed in a peripheral connective tissue sheath. The inner layer of connective tissue called tunica propria projects into the lumen of testis to produce seminiferous tubules. These seminiferous tubules are lined by spermatogonic epithelium which gives rise to spermatocytes. Spermatocytes are converted into the spermatids and then into the spermatozoa. Masses of spermatozoa can be seen lodged in seminiferous tubules. This tubular part is made up of somatic and germinal cells. The central portion of the testis is made of glandular tissue consisting of large and spherical interstitial glandular cells, fibroblasts, blood and lymph vessels. The histology of fish testis under control is given in (Fig.3). Testicular inflammation was documented as one of the common responses in both aquatic and terrestrial animals exposed to environmental toxicants (Sokal et al; 1985 Ruby et al; 1986 1987. Testis of Barbus carnaticus shows significant changes like disrupted seminiferous tubules and immature spermatogonia and general inflammatory response (Fig.4). when exposed to sublethal concentrations of Fenvalerate for different exposure periods. Cellular damage, inflammation and other histological damages are quite primitive. Inter tubular vacuoles clearly seen in all four sets of exposure (24, 48, 72 and 96 hours). . Exposure of Fenvalerate is responsible for histopathological damage of fish testis and vacuolization of tubular cells and distortion of seminiferous tubules, enlarged interstitial and haemorhage in inter tubular area in albino rats exposed to pesticides have been reported. Dutt and Dikshith 1973, Nigm et al; 1979 and Baronia \& Sahai 1993 Katti \& Sathyanesan 1985 observed exposure dependent on concentration mediated changes in testis of $C$. batrachus treated with lead . Degree of histological damage as is evident by the presence of large number of both inter and intra tubular vacuoles was maximum at 96 hours of exposure period. Gross condensation of spermatogenic cells which is evident by clump formation and appearance of inflammatory lesions are also quite prominent. Inflammatory cells seen in the testicular tissues of every treated fish, their number increases as the concentration of Fenvalerate 
increases i.e. the effect is exposure dependent and concentration mediated. Shrinkage of interstitial cells and vacuolation of tubular cells.is observed. Kinnberg, et al (2000) have also documented concentration dependent effects of Nanylphenol on testicular structure of the fish Xiphophorus maculatus.. Zutshi (2005) observed, the effect of Fenthion on the testis of Glossogobious giuris. They have observed reduction in size with spermatids and sperms in degenerative condition. Present study thus suggests that Fenvalerate is highly toxic to the fish Barbus carnaticus and cause damage to the internal structure of testis can result in decreased fertility potential in male Barbus carnaticus.

\section{REFERENCES}

[1]. Baronia, k. k. and Sahai, Y. N.1993 : DDT induced changes in the testis of albino rat, a histopathological study. J. Environ . Biol. 14 ,153-156

[2]. Dutta H M Nath A Adhikari S Roy P K Singh N K and Dutta Munshi J S 1994: Sublethalmalathion induced changes in the ovary of an air breathing fish, Heteropneustes fossilis a histological study Hydrobiologia. 294, 215-218

[3]. Dutta, k. k. and Dikshith, T. S. S.1973 : Histopathological changes in the testis and liver of Ekalux (EC 25) and Roger (Diamethoate) on the ovarion recrudescence in a teleost

[4]. Ghosh T K 1986 : Comparative toxicological evaluation of two commonly used pesticides Guraya, S. S. (2000): The biology of gonadal development, sex differentiation, maturation and sex reversal in fish; cellular, molecular and endocrinological aspects. Proceeding of the Indian National Science Academy (PINSA).

[5]. Hossain Z M RahmanZ and Mollah M F A 2002 : Effect of dimecron 100 scwon Anabas testudineus , Channa punctatus and Barbodesgonio notus ndan J. Fish, 49 415-417.

[6]. Johnson L L E Cartilar T K Colier B BMc Cain and U Varansi 1998 : Contaminant effects of ovarion development in English sole parophrys vetuler from Puget sound . Con. J. Fish, Aquat. Sci, 45. 2133-2146.

[7]. Kapur K and H S Toor 1978 : The effect of fenitrothion on reproduction of a teleost fish. Cyprins carpio communis (Linn) A biochemical study .BullEnvironContam. Toxicol 20 438-442.

[8]. Katti, S. R. and A. G. Sathyanesan 1985 : Chronic effects of lead and cadmium on the testis of the catfish Clarias batrachus Environ. Ecology,3 596-598

[9]. Khillare T K and S B Wagh 1987 ; Deveolopmental abnormalities induced by the pesticides in the fish Barbus stigma (Ham) Indian J. Applied and Pure Biol. 2(2). 73-76

[10]. Kinnberg, K., B. Korsgaard and P.Bjerregrd 2000 : Concentration dependent effects of nonylphenol on testis structure in adult platy fish Xiphophorus maculates. Mar. Environ. Res. 50 169-173

[11]. Kumar M Trivedi S P , Banerjee I and Soni A. (2000) : Influence of anionic surfactant, linear alkyl benzene sulphonate on ovarian phosphatase activity in Heteropneustes fossils (Bloch). Himalayan J. Environ. Zool., 14, 53-58.

[12]. Mani K and Saxena P K 1985 : Effect of safe concentrations of some pesticides on ovarian recrudescence in the feresh water murrel Channa punctatus (Bloch). A quantitative study Ecotoxicol Environ. Safety 9 241-249

[13]. McComic J H G N Stokes and R OHermantz 1989 : Oocyte atresia and reproductive success in fathedminowsr Pmephaies pometar exposed to acidified hard water environments. Arch EnvironContam. Toxicol.18. 204-207. 
[14]. Nagahama, Y. (1983) : The functional morphology of teleost gonads. In : Fish Physiology Reproduction, edited by Hoar W S Randall D J and Donaldson EM (New York Academic Press) 9A 233-275.

[15]. Nigam, S. K., B. C. Lakhad, A. B. Karnik, K. N.Thakore, D. K. Bhatt, K. Arvind Babu and S. K.Kashyap1979 : Effects of hexachlorocyclohexane feeding on testicular tissues of pure impredswiss mice. Bull. Environ. Contam.Toxicol. 23 431-437

[16]. Ptwardhan S A and Gaikwad S A 1990 : Effect of sumithion on gonads of mosquito fish Gambusia affinis (Baird and Girard ) In : Trends in Ecotoxicology (Eds R.C. Dalelaetal ) pp 235240. The Academy of Environmental Biology ,Lucknow. rats repeatedly exposed to pesticdes. Exp. Path. 8 363-370

[17]. Ruby S M D R Idler and P S Q Ying 1986 : The effect of sublethal cyanide exposure on plasma vitellogenesis levels in rainbiow trout, Salmo gardenari during early vitellogenesis Arch. Environ ContamToxicol. 15, 603-607

[18]. Ruby S M D R Idler and P S Q Ying 1987 : Changes in plasma, liver and ovary vitellogenin in landlocked atlantic salmon following exposure to sublethal cyanide Arch. Environ. Contam.Toxicol. 16,507-510.

[19]. Sarojini A and B Victor 1985 : Toxicity of mercury on the ovaries of the candean prawn .Curt. Sci, 54.398-340. Sarotherodon mossambicus. Uttar Pradesh J. Zool. 6(2).224231

[20]. Saxena P K and M Garg 1978 : Effect of insecticidal pollution on ovarion recrudesence in the freshwater teleost Channa punctatus. Ind. J. Exp. Biol. 16.690-691.

[21]. Shukla L A Srivastva D Meoxaoi and A KPandey A K 1984 : Effect of sub-lethal malathion on ovarion histopathology in
Sarotherodon mossanbicus Comp. Physiol. Eco. 9. 12 .

[22]. Singh S and Sahai S 1986 :Toxic effect of BHC on the immature ovary of Rasbora daniconius (Ham) Proc. Nat. Acad. Sci. India, 56 (B), 106110

[23]. Sokal, R. Z., C. E. Madding and R. S. Swerdloff 1985 :Lead toxicity and the hypothalamic pituitary testicular axis.Biol. Reprod., 33, 722728.

[24]. Yasuno M S Hatakeyama and M Miyashita 1980 : Effect of reproduction in the Guppy (Poecili areticulatus) under chronic exposure to temphos and fenitrothion. Bull. Environ.Contam. Toxicol. 25, 29-33.

[25]. Zutshi, B.2005 : Ultrastructural studies on the effect of fenthion on pituitary (GTH Cells ) and testis of Glossogobious giuris (Ham) during breeding phase J Environ. Biol. 26, 31- 36

\section{Cite this article as :}

A M Vibhandik, R B Gaikwad, G P Wani, "Fenvalerate Induced Changes in Histological Structure of Gonads of Freshwater Teleost Fish Barbus Carnaticus", International Journal of Scientific Research in Science and Technology (IJSRST), Online ISSN : 2395-602X, Print ISSN : 2395-6011, Volume 6 Issue 2, pp. 138-142, March-April 2019. Available at doi : $\quad$ https://doi.org/10.32628/IJSRST196218 Journal URL : http://ijsrst.com/IJSRST196218 